\title{
The Old Javanese Kapiparwa and a Recent Balinese Painting
}

\author{
Adrian Vickers
}

On a visit to Bali a few years ago, I was asked to identify a painting by the leading classical artist of Bali, I Nyoman Mandra, which featured the monkey hero Hanuman, or Anoman as he is known in Bali. ${ }^{1}$ At first the painting was a mystery to me, since it did not show the usual stories involving Anoman, although one scene looked like the visit of Anoman to Sita in Rawana's asoka garden. Solving the mystery of this painting led me to greater insights into the Balinese iconography of Anoman, and ultimately led me to greater understanding of why Anoman is regarded as a significant figure of power in Java and Bali. While it offers no direct textual insights into the Old Javanese KR, the painting demonstrated the importance of the narrative accretions and variations that have grown around the text.

I Nyoman Mandra (born 1946) is the main teacher of the classical style continued by the village of Kamasan, in Klungkung, and my mentor in the research I have carried out since 1978 on Kamasan art. We have often discussed the fact that there are many narratives in existence in Bali, but only a few of these are commonly known and used by Balinese painters. Nyoman's interest has always been in utilizing the full repertoire of stories, and he regularly sought out dalangs (wayang puppeteers) and others knowledgeable in such narratives. During the twentieth century Kamasan village had around a dozen dalangs, including many members of Nyoman's descent group, but they had almost died out by the twenty-first century, the last dalang of Kamasan being Pan Sadera, a neighbour of Mandra's.

1. The research for this paper was carried out as part of an Australian Research Council Linkage Project Grant, held in conjunction with the Australian Museum and the Batuan Project. The author would like to thank the participants in the Jakarta conference for discussion, Chris Carlisle, Adrian King, and especially Nyoman Mandra, and to Leo Haks for providing Figure 2. I will follow Modern Balinese pronunciation for the spelling used in this article. 


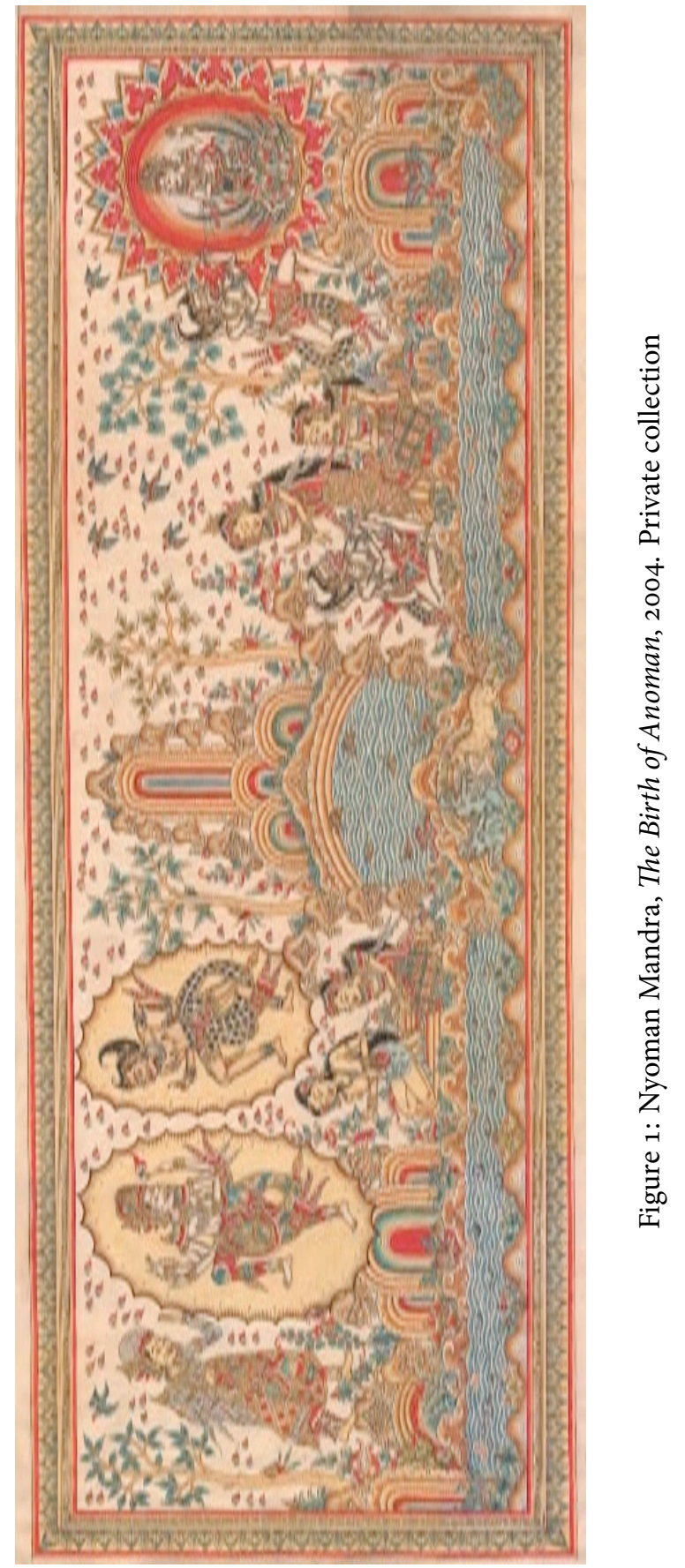

Adrian Vickers - 9789004253766 
The painting had been commissioned by Chris Carlisle, a long-term resident of Bali, who was involved in a project in Karangasem, and had taken Nyoman to the area to ask him if he would provide a painting to illustrate the sense of the area. Nyoman spent a long time in the cool and pleasant greenery of the Karangasem hills pondering what he would do. As with other works, he meditated on the subject matter of the painting, then produced this work in 2004, without providing an explanation as to what it depicted. This was not unusual, as Nyoman is often very loathe to talk about the meanings of his paintings, and clearly this had some kind of deep connection to his experiences in Karangasem.

One of the Balinese who worked on the project with Chris, and his business partner Adrian King, suggested a narrative explanation. ${ }^{2}$ Like me, the Balinese craftsman thought the scene of Anoman kneeling before a woman of high rank showed the scene of Anoman and Sita. But there was one crucial difference. Usually in depictions of the asoka grove, Sita is shown giving Anoman a ring, in token of her love for Rama. There was no ring in the right-hand scene. Further, this explanation did not really help solve the problem of the left-hand scene, which showed the gods Siwa (the white figure surrounded by an aureole) and Bayu (Pawana, the other figure surrounded by an aureole, whose iconography is identical with that of his son, Bima). In that same scene was a priest on the extreme left-hand side of the painting, holding up his hand in a gesture that may indicate surprise, and a seated, partially-clothed woman with something in her hand, and a servant seated behind her. The Balinese collaborator suggested that the right-hand scene might show the origins of Bima, from the $\mathrm{Ma}$ habharata, but that story did not explain all the figures in the scene, and also did not explain why two completely different narratives would appear in the same painting. The servant was also the same as the one who sits behind the high-ranking woman on the right, so presumably the partially-clothed woman and the high-ranking woman were one and the same. On the extreme right, Anoman is shown attacking the sun-god, Aditya (Surya), who was seated on his divine vehicle, Aruna. Between the two scenes was a shape indicating a mountain in Kamasan iconography, and there was water all around, consistent with a garden or jungle setting.

The partial scene of Anoman and Aditya was something I had seen in a number of modern Balinese paintings, including two from the 1930 s that came from Ubud. These works depicted Anoman actually trying to eat the sun, and the presence of the highest God, Atintya, trying to prevent this. Such a scene

2. Personal communication Adrian King in an email to me (28-02-2008). 
is not mentioned in the Kakawin version of the Ramayana, in fact the Old Javanese $\mathrm{KR}$ was not much help in explaining the other aspects of the painting either. The scene where Anoman goes to the asoka grove did indeed contain many references to the wind (Bayu) and the sun, hinting that there were levels of meaning that have not been explored in this passage, but that did not help identify the subject matter of the painting.



Figure 2: I Dewa Nyoman Leper, Anoman trying to eat the Sun, $55 \times 37.5 \mathrm{~cm}$. Pengosekan, 1930s, formerly Haks and Maris collection (188), originally collected by Gregory Bateson and Margaret Mead ${ }^{3}$

3. There is a more recent painting of this scene (possibly from the 1970s) in the Wredi Budaya Art Centre, Denpasar, painted by Gusti Made Baret, from the same village as Dewa Leper. 
Trying the Uttarakanda, the prose version of stories leading up to the Ramayana, was also not helpful, and Zoetmulder's guide (1974) to Old Javanese literature made no mention of these stories. The only other source of different types of Parwa or prose literature of the epics, Ensink's study of the Sutasoma episode in the Cantakaparwa (1967), was more helpful. Ensink's description of the 'encyclopædic' nature of the Cantakaparwa indicated that it contained a number of sub-texts, one of which, the Kapiparwa, or 'Monkey Parwa', told the story of Anoman, Bali and Sugriwa. The earliest reference to this text that Ensink (1967:12) could find came from the middle of the nineteenth century, when Friederich referred to the existence of the text. ${ }^{4}$ This was then one of the other prose works that held 'branch stories' to the Ramayana. Creese's guide (2004b) to the Hooykaas-Ketut Sangka collection of Balinese manuscripts indicated that there were six prose versions of the Kapiparwa and two poetic versions or Parikan.

The Kapiparwa turned out to hold the key to the story. There were several versions of this text in the Hooykaas-Ketut Sangka collection, and although they usually contain similar narrative elements, the variations between them were quite wide. The longest version, of 53 pages, came from Puri Madura, Karangasem, while other prose versions came from Jadi in Tabanan, Geria Duda in Selat, Karangasem, and Puri Kawan, Singaraja. ${ }^{5}$ These contained many other stories of high priests and other figures who were related to the narrative of the Ramayana. I selected the version from Geria Pidada Klungkung ${ }^{6}$ because this priestly house is the closest geographically to the village of Kamasan. Kamasan provided court artists to the high king of Klungkung, to whom Geria Pidada supplied high priests. The village and the priestly house had other connections, including paintings and an illustrated manuscript now in Geria Pidada that had originally come from Kamasan (Vickers 1982).

On first impression, the Kapiparwa was the kind of text that recorded narratives used in wayang performances. The language was not very difficult and included Balinese words (for example mbok, 'sister'), meaning that it could even have been written down very recently. The large variations between manuscripts would also confirm this impression. Longer versions of the text treated various Bhagawan or semi-divine priests at length, but also contained a number of key stories about the monkeys who appeared in the Ramayana. The text usually

\footnotetext{
4. Strangely the word kapi does not have an entry in KBNW.

5. HKS 2046, 1342, 1592 and 3649 (423.22, 24.08, 29.48 and 118.08) respectively, note that in the on-line database the Geria Duda version is described as having 7 pages, but actually has 15 . 6. $\mathrm{HKS}_{1835}(36,4)$.
} 
began with the story of Bhagawan Gottama. The name Kapiparwa comes from the fact that it dealt with histories of the monkeys (kapi), especially the story of (Su)Bali and Sugriwa, of their twin meditations, and of the conflict in which Rama intervened. Bhagawan Gottama was the father of Anjani (or Naranjani or Ranjani) by Dyah Jambikawati. Such was Jambikawati's beauty that the Sungod, Aditya, wished to have sex with her, and gave Anjani a gift of the cucupu manik-astagina, a jewel of power, so that she would keep quiet about this. Jambikawati gave birth to twins, (Su)Bali and Sugriwa. The twins were induced by a student of Gottama to ask Anjani for the manik-astagina, which she said came from a great priest. They then went to their father to ask him about this, and when he asked Anjani about the jewel, he cursed her and attempted to destroy it by splitting it into pieces. In fighting to get the split jewel, Bali and Sugriwa were turned into monkeys. ${ }^{7}$

All version of the Kapiparwa that I could locate described the birth of Anoman. Anjani journeyed with her brothers to a mountain forest, at the lake of Taman Kaliwarna, where they meditated in an attempt to have the curses lifted from them. At the peak of the mountain the brothers fought with Dasagriwa or Rawana, ${ }^{8}$ the king of Selamra, causing the animals in the mountain forest to flee. They then went to Giri Semi (Spring Mountain, literally Mount Sprouting Seeds), to meditate. Ranjani went to the north, above Selasayana. Her asceticism was to eat whatever she found near her sitting place, which was on a rock.

Siwa (Pasupati; Guru) was disporting with the Goddess at Giri Semi. The sight of the beauty of the mountains aroused Siwa, and they had sex; but Bhatara Bayu saw them and was jealous (kemburu) and enraged at their violation of the site. Disturbed by the wind, Siwa's sperm fell on a banyan leaf, which was then carried by the wind/Bayu onto the lap of Anjani. She ate it, and became pregnant, giving birth to a white baby in the form of a monkey. A voice came from the sky, telling her that this was a child unmatched in power (sakti) called Maruthi because he was born of sperm carried on the wind (marutha).

The child was hungry, and asked his mother what was appropriate food. She said to look for something red in the East. When the Sun came up, Maruthi attempted to eat him, and almost succeeded. Siwa and Anjani had to stop him, since he would destroy the world. His mother explained that when she said something 'red in the East', she meant rambutan, manggis, kukap, salak or other fruits.

7. I have glossed over some of the complications of this story, which emphasizes the rivalry of the brothers. Initially Anjani is cursed to become a stone pillar.

8. Probably invoking a pun on 'forest': wana. 
Anoman asked for a boon from Siwa in return for not eating the Sun: that he be given human form. Siwa told him to bathe in the dirty pool at Suranadi. There Maruthi saw two bathing places (ertali), one muddy (putek), the other pure (suci). He bathed in the first and became a very handsome man. But despite a warning from Siwa, he then bathed in the second and resumed his monkey form.

Other versions of the text vary in their language, but the story-line is similar. This kind of variation is typical of orally-transmitted versions that are written down at different times and places, and is a product of the fact that these versions were taken and developed by performers, usually dalangs. Thus only skeletons of stories are preserved between versions (Bandem et al. 1983; Zurbuchen 1987).

Take for example the passage where Anoman is born and Anjani tells Anoman about what he can eat. In the Geria Pidada manuscript it reads like this:

Kunang ri wetu Sang Maruthi, alemeh citta Sang Rajani manaka tan payayah. Binuncal sireng sela-bajra. Bentar remuk tang sela kadi galepung. Mojar Sang Maruthi, 'Ih sang ibu, angapa kita muncal ranak ta inganika?' Mojar ibuniya, 'Kacandung sirebu menge ngemban kita, matang yan tiba. Pahungwa anaku'. Mojar Sang Maruthi, 'Udhu hibu, mangke nghulun atanya ikang sayogya panganku. Apan tan wruh nguhulun'. Mojar sang ibu, 'Udhuh anaku Sang Maruthibapa. Ana wenang pinakabhuktinta, apan sira wre. Yan anan bang metu Wetan, ya ta pangananta'. Mangkana ling ibuniya. (5b-6a)

At the birth of Anoman, Anjani expressed her distaste for this child without a father. She left him behind on a diamond stone. The stone split and shattered into pieces as if it were rice meal. Anoman said, 'Oh, mother, why have you put your son aside?' She replied, 'I've been cut in half' bearing you, thus you were born, thus your establishment my son'. Anoman said, 'Oh mother, now I'm asking what I should eat, because I have no idea'. His mother said, 'Oh my child, son of the Wind. The provisions that are appropriate for you to take, because you are a monkey, are what is red and found in the East. That is what you should eat'. Thus the words of his mother.

9. Is this an allusion to the versions of the story where Anoman (or Anggada) is born by cæsarean? This section of the text is mostly in Balinese, for example using buncal instead of Old Javanese buncang. 
In the Jadi text this passage is:

... pira lawasniya ameteng, mijil ta were, mangaran Sang Maruthi, samangkana sabda sakeng Akasa, sinawut den ibuniya, binuncang ring sela maratha, bentar remuk sila ika, mojar sang Anoman: 'Ih Ibunku Sang Narenyani, kadi punapa, yang Ibu teka binendem, ranak hinganika, aneng sila meratha?' Mojar Ibuniya: 'Huduh anak inghulun, dudu ingsun ngamet sira, mengo Ibunira tiba aneng sela', mangkana lingira Ibuniya, Mojar Sang Anoman: 'Ih Ibunku Sang Narenyani, ri sedeng ingsun maseduk, tan weruh ring papangan'. Mojar Dhyah Narenyani, lawan tanayanira: 'Huduh anakingsun, Sang Anoman, ana wenang binukti de sira, apan sira marupa were, ana abang tumbuh kangin, yatika papangananta, mangkana lingniya Sang Ibu. $(12 \mathrm{a}-12 \mathrm{~b})^{10}$

After a night, a monkey was produced, called Anoman, as the voice from the Sky decreed. His mother responded by casting him aside on a flat rock. The rock split and shattered, and Anoman said: 'Oh Mother Anjani, why have you cast aside your son onto this flat rock?' His mother replied, 'Oh my son, it's not that I wanted to take you, that's why I turned aside and put you on the stone. Thus spoke his mother. Anoman said, 'Oh mother Anjani, I'm hungry, and don't know what to eat'. Anjani spoke to her son: 'Oh my son, Anoman, the provisions that are appropriate for you, because you have the form of a monkey, is what is red and comes up in the East, that is your food. Thus her words, the mother.

We see here a common framework of key words, but intense variation between them, as would be expected with a performed version of narrative frameworks that are handed down orally and only written as a kind of aide memoir. While it would be tempting to say that the second version is the oldest because it has more Kawi or poetic language, it also includes Balinese words (such as mase$d u k$ ), and could be a later version which has been re-elaborated to be closer to Old Javanese. The Parikan versions of the text are much more elaborate, but they are a separate form, since they are a different type of text. Ubud paintings of the story of Anoman eating the sun, such as the one illustrated above, show another variant of the story with the introduction of the figure of Atintya, the Supreme Being. Atintya also features in narratives involving the hero Bima, such as the Nawaruci or Dewaruci.

The birth of Anoman episode from the Kapiparwa is significant because of its commonalities, as well as differences, with other South and Southeast Asian 10. I have kept the punctuation provided by the transcribers. 
versions of this event. In some Indian versions of the story of Anoman, his father is Rama, and this version is followed by the Malay Hikayat Serri Rama and the Lao version of the Rāmàyana (Brockington 1985:296). ${ }^{11}$ In East Java, Rama is the father of Anoman. ${ }^{12}$ In other versions Anjani eats food distributed by Dasaratha, but carried by Bayu (Pawana), and at the same time her child is an incarnation of Siwa. ${ }^{13}$ A version very close to the Kapiparwa story is found in India, and Lutgendorf summarizes various stories, including a recent version of this, called the Hanuman Ràmāyana (Lutgendorf 2007:117-34). The Thai Ramakien and Burmese Rama Thagyin belong in this same tradition, although in them Bayu places weapons in the open mouth of Sawaha (Anjani), causing the birth of Hanuman (Brockington 1985:301; Toru 1994:317). In these and other Southeast Asian versions, Anjani is cursed by her mother to give birth to a monkey, because she reveals to her father her mother's infidelity with Aditya. The motif of the fallen sperm is found in both the Rama and Siwa versions of paternity, but in some versions the sperm is eaten directly because Anjani is meditating standing on one leg with her mouth open. In others it falls into her ear (Barrett 2002). Given the intense variation in these stories, it seems unlikely that there is a single transmission of one Indian version to Bali via Java. Rather, we are looking at potential interaction between versions of the story, and possibly on-going reciprocal contact between India and Southeast Asia that muddies any lines of transmission.

The Kapiparwa explains all aspects of Nyoman Mandra's painting, ${ }^{14}$ beginning with the appearance of someone who is presumably Bhagawan Gottama on the far left, and showing Bayu chasing away (namely, interrupting the sex of) Siwa. Thus the woman in the forest is Anjani, who is shown with the leaf in her hand. On the right we see Anoman receiving his eating instructions from his mother, and then wrongly trying to eat the Sun. When I went back to Nyoman with this identification he affirmed it, but without elaboration.

More than this, the Kapiparwa explains why Anoman is a monkey and yet a figure of power. He is a descendant of Bhagawan Gottama, but the son of Siwa,

11. My thanks to Roy Jordaan for drawing my attention to this book, and for other helpful comments.

12. Personal communication Jumadi (04-05-09).

13. See http://hinduism.about.com/library/weekly/aa052801b.htm and http://www.hinduism.co.za/hanuman.htm (accessed 16-11-2010).

14. Thus also Nyoman Mandra's work does not indicate direct influence from the confusing project of Kam (2000:46), by which Kamasan artists were commissioned to paint Ramayana scenes based on other Southeast Asian versions of the story. A similar, but different, version of the birth of Anoman was thus painted by Mandra's student, Wayan Pande Sumantra, but showing Indra chasing Anoman, based on the Thai Ramakien. 
which is why both Anoman and Siwa are white. At the same time, Aditya is Anoman's spiritual step-grandfather, and is addressed as such when they talk, and Aditya calls Anoman his grandson (putu). Likewise Bayu is, by mediation, also the father of Anoman. Anoman shares iconographic features with Bayu, especially the fact that he wears a black-and-white chequered loin-cloth.

The link to Bayu explains a connection Balinese make between Anoman and Bima, which is otherwise mysterious. There is one early twentieth-century Kamasan painting, by Pan Remi, that shows a meeting between Anoman and Bima where they come into conflict. Anoman and Bima have similar iconography: both have the 'prawn claw' (supit urang) coiffure of the semi-divine heroes of the epics, and both wear very little clothing except for the chequered (poleng) loin cloth. In Balinese ritual use these poleng cloths, as the union of opposites, represent power (sakti). The heroes' conflict is ended by the intercession of their father, the god Bayu, who is iconographically identical to Bima, except that he has the aureole and what Forge refers to as a 'god spot'. Forge (1978:25), who collected the painting, could find no narrative text to elucidate this work, but commented on how both heroes are matched in power, and are effectively reflections of each other, meaning that one cannot defeat the other. However, the third Parwa of the Mahābhärata, The Book of the Forest, has a section 'The Tour of the Sacred Fords', in which Bima, while journeying through the forest, fails to recognize Anoman (Van Buitenen 1975:501-4). The latter says that Bima will be allowed to pass the area where the aging monkey lives if Bima can lift his tail, but he fails to do so, and thus recognizes Anoman as his older brother. In the original version the two do not actually fight, but it seems that Balinese localizations of the story amplify the challenge into a full conflict, shifting the emphasis to equality of the heroes.

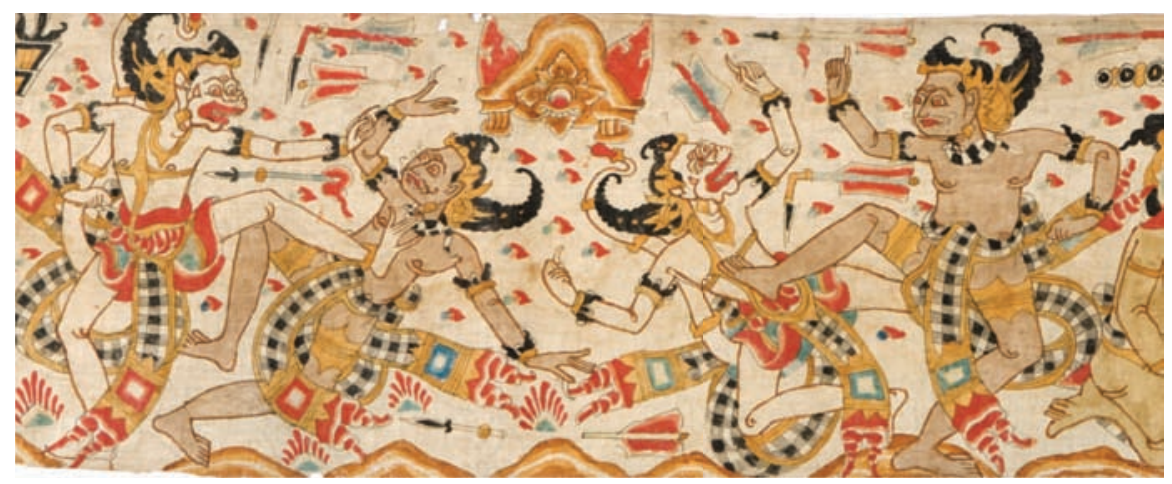

Figure 3: Detail of the Battle between Anoman and Bima by Pan Remi, Kamasan, circa $1910,30 \times 524 \mathrm{~cm}$. Australian Museum, Photograph Emma Furno. 
Nyoman Mandra's painting shows Bayu and Anoman in similar positions. Both are literally ascendant figures, rising up to attack (or at least put on the defensive) major gods: Siwa and Aditya. The painting emphasizes their power, their roles as figures who can intervene in the world.

The associations of Anoman with Bayu, and hence with Bima, are significant because they are general associations of power. These clarify why both Anoman and Bima are popular figures in Bali, and may explain links between the two that go back over many centuries, including the appearance of statues of Anoman in the Majapahit period (Klokke 2006). Klokke, who is the only person to have written about these statues, observes that their appearance comes at the same time as the growth of what Stutterheim (1956) identifies as a Bima cult, and coincides with developments in the worship of Anoman in India.

It may be that the Balinese beliefs about Anoman and Bima show that in the case of East Java, we are less talking about a cult specifically of Bima, and more about a cult of power that has Siwaite origins and involves forms of divine intercession. The most elaborate exposition of Bima's power is found in the Kamasan paintings on the ceiling of the Kerta Gosa or Hall of Justice at Klungkung. In these Bimaswarga scenes, Bima is shown purifying the souls of his parents and carrying them out of hell (purgatory) and into heaven (Vickers 1979). The priestly role assumed by Bima indicates that, as a figure of power (sakti), he has the ability to intervene between the human and divine worlds, and also has a kind of protective power. His power is partly related to his character as a figure of force. He has a strong and aggressive character, one that involves physical strength and harnessing of anger. Anoman too is a figure of strength, with the added ability to fly. Anoman literally has world-destroying potential, and his links with such power, and with Siwa, illustrate the same kind of power that Stutterheim links to Bima. This however casts doubt on Stutterheim's notion of a 'Bima cult', since this interest in power is more usually part of left-hand-path or Bhairawaite Tantric practices of deliverance. It has become a part of what I would call mainstream Balinese religion. As Hildred Geertz has shown, the pervasiveness of forms of power outside those perceived by the senses is a major Balinese preoccupation. It is certainly a preoccupation of painters (Vickers 1980; Geertz 1994).

Nyoman Mandra's painting is not just about power. It is a painting about landscape as well. The mountain forest dominates the centre and foreground of the painting, that is the painting literally revolves around the mountain in the middle. Within this beautiful space we see disruption: the conflicts of the gods and the attack by Anoman on Aditya. The disturbance of the animals in the 
foreground is also part of that sense of disturbance. But there is another figure mediating between the disruption of the gods and demigods, and the beauty of the landscape: Anjani. She is the receptacle of the power of the gods, but has power over Anoman, as shown by his bowing before her. It needs to be remembered that the concept of sakti in Bali is not the same as the Indian notion of the goddess-wife as source of power. However, in this painting we also see Anjani as a source of power, just as in the text she is a transmitter of power (remembering that she was performing asceticism, as were her brothers). Anjani partakes in the beauty of the landscape, and her power is related to that. The painting is an exposition of the balance of power in the landscape, with a complex explanation of the gods' powers. Effects of power and results of actions of the gods are not direct, but happen as unintended consequences of the passions of the gods. There is not a sense of omniscience in operation here, but rather chains of cause-and-effect governing the power of certain beings to affect nature. The painting is profoundly philosophical, and at the same time, a meditation on the beauty of nature and its effects. 